\title{
Correction to: Treatment patterns and effectiveness of patients with multiple myeloma initiating Daratumumab across different lines of therapy: a real-world chart review study
}

Shebli Atrash'1 ${ }^{1}$ Philippe Thompson-Leduc ${ }^{2 *}$, Ming-Hui Tai ${ }^{3}$, Shuchita Kaila ${ }^{3}$, Kathleen Gray ${ }^{3}$, Isabelle Ghelerter ${ }^{2}$, Marie-Hélène Lafeuille ${ }^{2}$, Patrick Lefebvre ${ }^{2}$ and Adriana Rossi ${ }^{4}$

Correction to: BMC Cancer 21, 1207 (2021)

https://doi.org/10.1186/s12885-021-08881-7

Following publication of the original article [1], it was identified that due to typesetting mistakes, an unfinalized version of the article were published. The following changes have been implemented.

1) The corresponding author's email address has been corrected: Philippe.Thompson-Leduc@analysisgr oup.com

2) In table 1 , note 2 , the full reference is: Palumbo A, Avet-Loiseau H, Oliva S, Lokhorst HM, Goldschmidt $\mathrm{H}$, Rosinol L, et al. Revised international staging system for multiple myeloma: a report from international myeloma working group. J Clin Oncol. 2015;33(26):2863-9. https://doi.org/10.1200/JCO. 2015.61.2267

3) In table 2, note 3, the full reference is: Dimopoulos MA, Oriol A, Nahi H, San-Miguel J, Bahlis NJ, Usmani SZ, et al. Daratumumab, Lenalidomide,

The original article can be found online at https://doi.org/10.1186/s12885021-08881-7.

*Correspondence: Philippe.Thompson-Leduc@analysisgroup.com

${ }^{2}$ Analysis Group, Inc, 1190 avenue des Canadiens-de-Montréal, Deloitte

Tower, Suite 1500, Montreal, QC H3B 0G7, Canada

Full list of author information is available at the end of the article and dexamethasone for multiple myeloma. $\mathrm{N}$ Engl J Med. 2016;375(14):1319-31. https://doi.org/10.1056/ NEJMoa1607751

4) In table 3, note 1 , the full reference is: Kumar $S$, Paiva B, Anderson KC, Durie B, Landgren O, Moreau P, et al. International myeloma working group consensus criteria for response and minimal residual disease assessment in multiple myeloma. Lancet Oncol. 2016;17(8):e328-e46. https://doi.org/10.1016/S14702045(16)30206-6

5) In table 4, note 2, the full reference is: Kumar S, Paiva B, Anderson KC, Durie B, Landgren O, Moreau P, et al. International myeloma working group consensus criteria for response and minimal residual disease assessment in multiple myeloma. Lancet Oncol. 2016;17(8):e328-e46. https://doi.org/10.1016/S14702045(16)30206-6

6) In the section, Treatment patterns of first daratumumab-based regimen, paragraph three: The text should not have been in bold typeface.

7) In the section, Treatment patterns of first daratumumab-based regimen, paragraph three: " 3.3 Clinical outcomes" Was removed from the end of the paragraph.

8) In the abbreviations list, " $3 \mathrm{~L}$ : Third line or later" was updated to "3 $\mathrm{L}+$ : Third line or later"

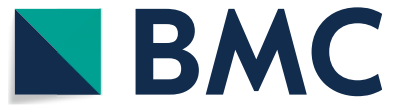

(c) The Author(s) 2021. Open Access This article is licensed under a Creative Commons Attribution 4.0 International License, which permits use, sharing, adaptation, distribution and reproduction in any medium or format, as long as you give appropriate credit to the original author(s) and the source, provide a link to the Creative Commons licence, and indicate if changes were made. The images or other third party material in this article are included in the article's Creative Commons licence, unless indicated otherwise in a credit line to the material. If material is not included in the article's Creative Commons licence and your intended use is not permitted by statutory regulation or exceeds the permitted use, you will need to obtain permission directly from the copyright holder. To view a copy of this licence, visit http://creativecommons.org/licenses/by/4.0/. The Creative Commons Public Domain Dedication waiver (http://creativeco mmons.org/publicdomain/zero/1.0/) applies to the data made available in this article, unless otherwise stated in a credit line to the data. 
These corrections were typesetting errors and do not influence the results of this article. The publishers apologise for this error. The original article [1] has been updated.

\section{Author details}

${ }^{1}$ Levine Cancer Institute, Charlotte, NC, USA. ${ }^{2}$ Analysis Group, Inc, 1190 avenue des Canadiens-de-Montréal, Deloitte Tower, Suite 1500, Montreal, QC H3B 0G7, Canada. ${ }^{3}$ Janssen Scientific Affairs, LLC, Horsham, PA, USA. ${ }^{4}$ Division of Hematology and Medical Oncology, Weill Cornell Medicine, New York, NY, USA.
Published online: 02 December 2021

\section{Reference}

1. Atrash S, Thompson-Leduc P, Tai, MH., et al. Treatment patterns and effectiveness of patients with multiple myeloma initiating Daratumumab across different lines of therapy: a real-world chart review study. BMC Cancer. 2021;21:1207. https://doi.org/10.1186/s12885-021-08881-7.
Ready to submit your research? Choose BMC and benefit from:

- fast, convenient online submission

- thorough peer review by experienced researchers in your field

- rapid publication on acceptance

- support for research data, including large and complex data types

- gold Open Access which fosters wider collaboration and increased citations

- maximum visibility for your research: over 100M website views per year

At BMC, research is always in progress.

Learn more biomedcentral.com/submissions 